Thus, the result obtained on the ability of dihydroquercetin to inhibit the adhesion process in microorganisms and the formation of a biofilm can serve as a contribution to the further study of the use of flavonoids, including for the treatment of instrumentation and intravenous systems as a means of preventing catheter-associated infections.

\title{
References
}

1. Beloborodova N.V. Klinicheskoe znachenie mikrobnyh bioplenok // INTERNIST. - Vserossijskaja obrazovatel'naja Internet-sessija dlja vrachej. - 30 marta 2011.

2. Bondarenko V.M. Faktory patogennosti bakterij i rol’ v razvitii infekcionnogo processa // Zh.M.E.I. - 1999. - № 5. - S.34-39.

3. Gostev V.V., Sidorenko S.V. Bakterial'nye bioplenki i infekcii // Zhurnal infektologii. - 2010. - 2(3) - S.4-15.

4. Eroshenko D.V., Korobov V.P. Vlijanie ionov dvuhvalentnyh metallov na adgeziju i obrazovanie bioplenok bakterijami Staphylococcus epidermidis // Fundamental'nye issledovanija. - 2014. - № 12. - Ch.8. - S.1663-1667.

5. Seregina N.V., Chestnova T.V., Zherebcova V.A., Hromushin V.A. Obzor biofizicheskih osobennostej mikrobnoj adgezii // Vestnik novyh medicinskih tehnologij - 2008. - T.XV. - № 3. - S.176.

6. Suhorukova M.V., Jejdel'shtejn M.V., Skleenova E.Ju., Ivanchik N.V., Timohova A.V., Dehnich A.V., Kozlov R.S. Antibiotikorezistentnost' nozokomial'nyh shtammov Enterobacteriaceae v stacionarah Rossii: rezul'taty mnogocentrovogo jepidemiologicheskogo issledovanija MARAFON v 2011-2012 gg. // Klin. mikrobiol. antimikrob. himioter. - 2014. - T.14. - № 4. - S.254-266.

7. Caserta R., Takita M.A., Targon M.L., Rosselli-Murai L.K., de Souza A.P., Peroni L., Stach-Machado D.R., Andrade A., Labate C.A., Kitajima E.W., Machado M.A., de Souza A.A. Expression of Xylella fastidiosa fimbrial and afimbrial proteins during biofilm formation // Appl. Environ. Microbiol. - 2010. - Jul. - Vol.76. - N.13. - P.4250-4259.

8. Denman C.C., Brown A.R. Mannitol promotes adherence of an outbreak strain of Burkholderia multivorans via an exopolysaccharide-independent mechanism that is associated with upregulation of newly identified fimbrial and afimbrial adhesins // Microbiology. - 2013. - Apr. - N.159. - Pt4. - P.771-781.

9. Labigne-Roussel A., Schmidt M.A., Walz W., Falkow S. Genetic organization of the afimbrial adhesin operon and nucleotide sequence from a uropathogenic Escherichia coli gene encoding an afimbrial adhesin // J. Bacteriol. - 1985. - Jun. - Vol.162. N.3. - P.1285-1292.

DOI 10.22448/AMJ.2017.3.25-25

DISCUSSION ON THE DEVELOPMENT OF CLINICAL PHARMACY IN TRADITIONAL CHINESE MEDICINE HOSPITAL

\author{
Chunsheng Lin, Dongxue Liu, Jiaqian Wang
}

(The Second Affiliated Hospital of Heilongjiang University Of Chinese Medicine,Harbin 150000, China,E-mail : 393849651@qq.com)

Abstract In order to improve the quality of pharmaceutical care in traditional Chinese medicine hospital, it is necessary to carry out clinical pharmacy work. This paper analyzes the present situation of clinical pharmacy in Chinese medicine hospital, and points out that traditional Chinese medicine practitioners should participate in the treatment of traditional Chinese medicine. It plays an important role in the safe, effective and reasonable application of traditional Chinese medicine, and provides the source for the development of traditional Chinese medicine.

Keywords:ClinicalChinesepharmacy;Drug safety;Chinese pharmacist;Clinical efficay

Discussion In the development of clinical pharmacy work, first hospital leaders attach importance to work in medicine and medicine can not be divided on hospital pharmacy work attention, at the same time, pay attention to personnel training, election of a strong sense of responsibility, a high level of business personnel to participate in the professional learning, better service for clinical pharmacy. In the pharmacy management, should be regularly informed of the general assembly to prescription analysis, problems and hazards exist, in order to improve the level and quality of medical prescription, clinical significance of pharmacokinetics to the hospital medical staff academic report, introduces the main contents of clinical pharmacy, such as the importance and principle of the blood concentration monitoring, and the comprehensive analysis of the new drug safety to achieve medicine combination to improve the quality of medical treatment; set up to the pharmacist in charge for the leadership, as the backbone of the pharmacist pharmacy consultation department, the establishment of the pharmacy information room, provide information to the hospital pharmacy; set up to Dean LED the subjects responsible for the backbone of the Hospital Pharmacy Committee, carries on the macroeconomic regulation and control the whole hospital pharmacy work, avoid drug abuse, chaos into the purchase of medicines. In addition, it is necessary to strengthen the study of pharmacoeconomics, so that the drug is efficient, safe and economical to serve patients, to reduce the burden on patients.

\section{DOI 10.22448/AMJ.2017.3.25-26 \\ ELECTROACUPUNCTURE INCREASES AWAKE EEG ACTIVATION AND IMPROVES DAYTIME SLEEPINESS PER- FORMANCE IN OBSTRUCTIVE SLEEP APNEA AFTER STROKE}

\section{Dongyan Wang1,Jing Song1, Lei He1}

Heilongjiang University of Chinese Medicine, Harbin, China,15001.

Abstract Objective: The study aimed to observe the waking electroencephalography(EEG) biomarkers before and after electroacupuncture on the treatment of patients with OSA after stroke, and 